\title{
Landscape Damage Effect Impacts on Natural Environment and Recreational Benefits in Bikeway
}

\author{
Chun-Chu Yeh ${ }^{1}$, Crystal Jia-Yi Lin ${ }^{2}$, James Po-Hsun Hsiao ${ }^{3}$ and Chin-Huang Huang ${ }^{3, *}$ \\ 1 Department of Tourism and Hospitality, Transworld University, Yunlin 640, Taiwan; joyceyehh@gmail.com \\ 2 Department of Physical Education, National Taiwan University of Sport, Taichung 404, Taiwan; \\ lincrystal@ntupes.edu.tw \\ 3 Department of Sport Management, National Taiwan University of Sport, Taichung 404, Taiwan; \\ phhsiao@ntupes.edu.tw \\ * Correspondence: hch55@ntupes.edu.tw; Tel.: +886-4-2221-3108 (ext. 2005)
}

check for updates

Citation: Yeh, C.-C.; Lin, C.J.-Y.;

Hsiao, J.P.-H.; Huang, C.-H.

Landscape Damage Effect Impacts on

Natural Environment and

Recreational Benefits in Bikeway.

Diversity 2021, 13, 52. https://

doi.org/10.3390/d13020052

Academic Editors: Corrado Battisti,

Luca Luiselli and Michael Wink

Received: 22 November 2020

Accepted: 26 January 2021

Published: 29 January 2021

Publisher's Note: MDPI stays neutral with regard to jurisdictional claims in published maps and institutional affiliations.

Copyright: (c) 2021 by the authors. Licensee MDPI, Basel, Switzerland. This article is an open access article distributed under the terms and conditions of the Creative Commons Attribution (CC BY) license (https:// creativecommons.org/licenses/by/ $4.0 /)$.

\begin{abstract}
Landscape is an important element in outdoor sports recreation. Cyclists' perception of an environment reflects their interaction with the actual environment; they become aware of the recreation site through their primary receptive senses. As one popular bikeway in Taiwan, the landscape along Dong-Feng bikeway appeals to many cyclists. Nevertheless, the landscape was spoiled due to a soil conservation project. This study follows the theorem of planned behavior (TPB) and applies contingent behavior scenario to evaluate the recreational benefits and the damage effect of landscape. The empirical model uses travel cost method (TCM) to estimate the consumer surplus of cyclists. Under the scenario of damaged landscape, the number of trips went down 1.01 times and the recreational benefit dropped to NT\$750, making the cost of damaging the landscape to NT\$132 per person. The result indicates that the landscape of environment quality is crucial to cyclists, and it is important to preserve the natural environment of bike paths for developing the sport tourism sustainability.
\end{abstract}

Keywords: landscape; environmental quality; sport ecology; theorem of planned behavior; contingent behavior; impact

\section{Introduction}

Landscape is an element in outdoor recreation experiences [1]. Cycling is often considered as a useful way to reduce urban congestion and, improve people's health. Its contribution to social and environmental outcomes is not deniable. The demography, environment and geography are three important variables in bicycle tourism, which can also affect cyclists' choices of a bikeway [2]. Among the three variables, natural environment is a key resource of outdoor sport tourism $[3,4]$, because enjoying and experiencing the natural environment are important dimensions when taking sport tourism trips [5]; sometimes even the built landscape is designed to meet the specific requirements of the visitors [6]. Landscape is indeed important to sport tourists [7]. As one popular activity of sport tourism, bicycle tourism includes independent cycling as well as traveling for participating and spectating in organized events (Lamont, 2009) [8]. It can be defined as watching, involving in, or participating in cycling events [9].

Research about bicycle tourism focus mostly on motivations [7,10], social-economics [11], racing subculture [12], gender [13,14], and benefits thought [15]. Environmental factors in sport tourism were less discussed [16]. Previous studies identified environment and bicycle facilities as influencing factors in cyclists' preference $[17,18]$. Perić, Durkin, and Vitezić (2018) revealed that natural environment, scenic routes, safety, and security were the most important elements of sport tourism [19]. Yeh, Lin, Hsiao, and Huang (2019) performed contingent behavior method (CBM) to find that improving the quality of lighting facility and the landscape of bikeway would increase the intention and the recreational benefits 
of cyclists in central Taiwan [20]. After their study on the bikeway, construction of soil conservation project was performed by local government, however, the project spoiled the beautiful landscape of the bikeway.

Dong-Feng Bikeway, also known as the Green Corridor, is an attractive bikeway in central Taiwan. Making use of an old rail way, it connects Dongshi and Fengyuan districts in Taichung city. The bikeway runs for $12 \mathrm{~km}$ with trees on both sides forming a green tunnel for cyclists. There is also a river meanders on one side offering a soothing view to cyclists. Nevertheless, the landscape was damaged by a soil and water conservation project which uprooted trees with shallow roots on both sides of the bikeway for $100 \mathrm{~m}$ (See Figure 1). Since landscape is an important element of outdoor recreations [1], especially for cycling [21]. For cyclists, the interaction between landscape and technology is a regulating for their body on road [21]. The soil and water conservation project changed the landscape, where there were trees and shade are now replaced by barren concrete grids (Figure 1).

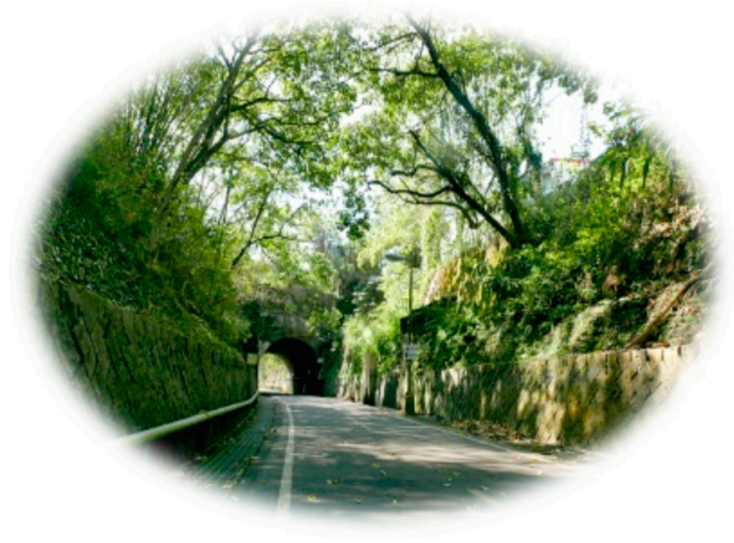

Before the construction

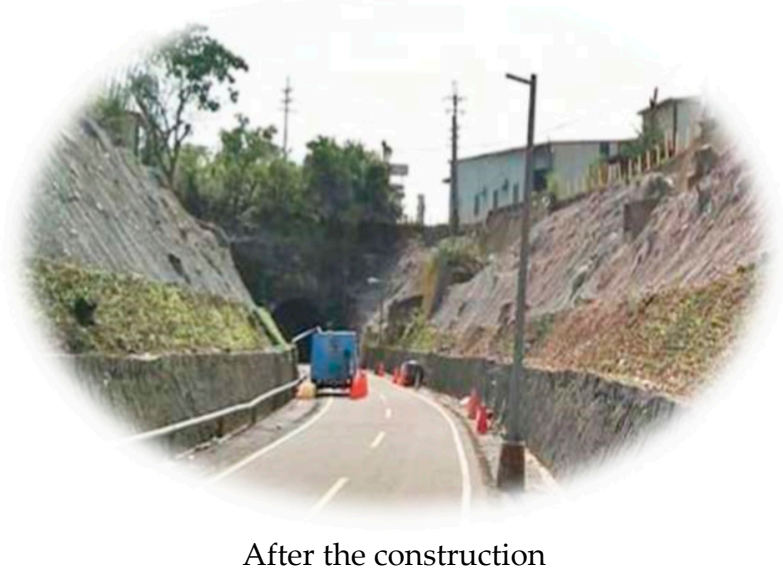

After the construction

Figure 1. The landscape of Dong-Feng Bikeway, before, and after the soil conservation project.

The soil and water conservation project got rid of the trees on both sides of the bikeway for $100 \mathrm{~m}$. This change in landscape was not welcomed by the cyclists, and influenced their intension for revisiting. The changing in behavior is consistent with the framework of the theory of planned behavior (TPB); depending on the evaluative judgment, different behaviors are formed. To better understand cyclists' destination decision behavior. This study also included contingent behavior question in the survey that based on travel cost method (TCM) to estimate the effect of landscape damage on Dong-Feng Bikeway.

The research on the damage effect of environment quality on bicycle tourism is scarce. The purpose of this study is to measure the monetary value of environmental damage and recreational benefits of cyclists on Dong-Feng Bikeway. The challenge of measuring the monetary value of landscape deterioration and recreational benefits of cyclists is that bikeways belong to non-excludability and non-rivalry public good, which is not usually directly revealed in market transactions; and the recreational benefits of sport tourists traveling to participate in recreational sports should be categorized as nonmarket benefits [22]. Therefore, methods for estimating non-market goods should be considered to evaluating the economic value of the landscape. This study will use the non-market method, TCM, to estimate the recreational benefits, and include contingent behavior questions to ask cyclists their intention to ride on the bikeway after the landscape is changed. The main contribution of this study is the evaluation of the cyclists' intention behavior and the effect of damaged landscape based on the framework of TPB and TCM. The finding also demonstrates that the quality of the landscape is one very important factor to bike tourism. 


\section{Materials and Methods}

\subsection{Literature Review}

Since landscape is a visible environment that includes aesthetic and symbolic properties, such as churches, farmland, tree-houses, mountain, lakes and so on, it becomes the background of a sports event and can affect participants' decision to choose a destination. However, environmental resources and the natural environment of a city could be negatively impacted by organizing mega sport events and the construction projects of building infrastructure and events venues [23]. To make sure that natural environment is not sacrificed for organizing sports events, along with sport and culture, International Olympic Committee (IOC) has made environment the third component of the Olympic movement [24]. The host communities should contribute to sustainable environment, innovation programs, and community through providing qualified personnel, excellent infrastructure, and green local products [25]. Environmentally friendly approaches should be adopted for the construction of the physical environment and the running of the activities.

Physical environment plays an important role in how tourists perceive their chosen destinations [26]. Perceived environmental quality can influence tourists' decisions [27]. Attractive environments or surroundings can draw cyclists to participate in cycling events [28]. Therefore, improving participants' perceptions of the environment is as important as improving the cycling infrastructure, and should be incorporated in the design of the built environment [29]. The effect of the environmental quality should not be overlooked in a demand model, and the recreational benefits should play a part in the decision-making of sport tourism related issues [30].

Environmental factors that can influence recreational cyclists' decisions include scenery, facilities, route choices, types of lanes, and grades of roadway [31]. Cyclists preferred routes that are well-provided with cycling facilities and have tourist attractions around [32]. Lamont and Buultjens (2011) analyzed the impediments to cycling tourism with an Australian sample. They found that cyclists' perceptions of road safety and infrastructure can affect their intention to choose a destination. Thus, the quality of bikeways is important to cyclists [33]. The research of Yeh et al. (2019) revealed that improving environmental quality of bikeways in landscaping and lighting facilities can significantly change cyclists' perceptions of a bikeway [20].

Good bicycle paths infrastructure, shaped by cyclists' preferences and technological development can induce more cycling activities. Increasing amenity-rich communities is seen as crucial to attracting cyclists [34]. When bikeways and their surrounding landscape are positively received by participants, they will influence participants' desires to take part in the same event and perhaps return to the area in the future [7]. However, there is little research on the damage of the landscape, and there is a lack of a theoretical framework to guide the research questions or hypotheses. Cunningham and Kwon (2003) followed TPB in sports event to fill the theoretical shortcomings in explaining sport consumers' game attendance behavior [35]. In this study, TPB was adopted as the research theorem. The landscape changed scenario meets contingent behavior approach. This study designed the contingent behavior question and adopted TCM to estimate the recreational benefits under the scenario of damaged landscape.

\subsection{Theoretical Basis}

The theorem of planned behavior holds that an individual's attitude, subjective norms and perceived behavioral control can all predict an individual's intention to participate in an activity [36]. Attitudes can be viewed as having a favorable or unfavorable feeling or opinion about something. Subjective norms refer to social expectations for a person to engage or not to engage in a given activity. Hagger, Chatzisarantis, and Biddle (2002) found a significant correlation between attitudes and intention [37]. The theoretical framework of TPB is a useful method in predicting sport spectator's intention to attend activities. Attitudes, subjective norms, previous behavior and perceived behavior were positively related to intentions to participate in sport activities [35]. Cunningham and Kwon (2003) 
argued that there is a lack of theoretical frameworks in the research of sport management to guide the research question [35]. This study tries to examine cyclists' attitudes towards riding on Dong-Feng Bikeway whose trees were removed for $100 \mathrm{~m}$ due to a soil conservation project. The framework of TPB can assist the research of this study. Respondents were asked the contingent behavior question that after the landscape of the bikeway was destroyed would they reduce the number of trips to Dong-Feng Bikeway. TCM is used to measure the numbers of trips and the monetary effect of recreational benefits $[20,38,39]$.

\subsection{Methodology}

How would the damage of the landscape affect the behavior and welfare of cyclists? This study tries to explore the possible impact on the intention of the cyclists after the quality of landscape has been changed. Would the damage of the landscape decrease the visitation of cyclists? This study tries to evaluate the deterioration effect of bikeway. This research tries to estimate the effect of spoiling the landscape. The most important contribution is that this study is based on the framework of TPB and the conception of contingent behavior as empirical method that adopted TCM to estimate the effect of landscape damage on bikeways.

The items of the environment quality questionnaire were taken from the literatures review, such as Bull (2006), Chen and Chen (2013), and Sener et al. (2009) [17,28,32]. The scale of environment quality questionnaire used Likert scale that from "strongly disagree, 1 " to "strongly agree, 5". The survey was performed in April, 2019. Four hundred twenty cyclists were asked to fill the questionnaire in random; among them, 382 respondents completed the questionnaire, yielded a response rate of $90.95 \%$. Exploratory factor analysis was used to extract the major components of environmental quality in Dong-Feng Bikeway.

Perceived value has been recognized as one important indicator to measure customers' intentions of rebuying [40]. For non-market goods research TCM and contingent valuation method (CVM) are popularly used. TCM uses the revealed preference approach to measure recreational benefits; while CVM uses stated preference approach to measure non-use values. However, the main of problem of CVM is that the willingness to pay (WTP) of the hypothetical scenario differs from the real one; this is a hypothetical bias [41]. In order to mitigate the hypothetical bias of CVM, this research adopts TCM to measure the recreational benefits and environmental effect on Dong-Feng Bikeway. The recreational benefits of cyclists were calculated from the demand function. The travel cost is estimated based on the distance to the destination from and return to the respondents' home [42,43].

In addition to cyclists' actual expenditures on site, the opportunity costs of time should be included in the travel cost and substitute sites cost [44]. McConnell and Strand (1981) suggested that opportunity cost can be estimated using 33.3\% -wage rate as cost of travel time [45]. The substitute cost must be included in the demand function. The recreational benefits of the cyclists will be overestimated, if the substitute cost is omitted [46]. This study selected Kenting National Park in the south of Taiwan as the substitute site, based on the information of pre-test survey.

The empirical model adopted on-site Poisson to estimate the recreational benefits of cyclists who rode on Dong-Feng Bikeway. The parameter of Poisson distribution is $\lambda_{i}$, Which is derived from the exponential function, i.e., $\lambda_{i}=\exp \left(z_{i} \beta\right)$, and $\beta$ are parameters of the independent variables $z_{i}$. The log-likelihood of Poisson function cab be expressed as $\ln L$ :

$$
\ln L=\sum_{i=1}^{T}\left[z_{i} \beta x_{i}-e^{z_{i} \beta}-\ln \left(x_{i} !\right)\right]
$$

On-site samples incurred the biases of non-users and endogenous stratification. Shaw (1988) developed on-site Poisson model to correct the biases [47,48]. Therefore, the adjusted function is $h\left(x_{i} \mid x_{i}>0\right)=\frac{e^{-\lambda_{i}} \lambda_{i}^{x_{i}-1}}{\left(x_{i}-1\right) !}$. The equation can be re-written as follows, where $w_{i}=x_{i}-1$.

$$
h\left(x_{i} \mid x_{i}>0\right)=\frac{e^{-\lambda_{i}} \lambda_{i}^{w_{i}}}{w_{i} !}
$$


Equation (2) expresses in $w_{i}$. After corrected the truncated and endogenous stratification, the log-likelihood function of on-site Poisson is [30]:

$$
\ln L=\sum_{i=1}^{T}\left[z_{i} \beta\left(w_{i}\right)-e^{z_{i} \beta}-\ln \left[\left(w_{i}\right) !\right]\right]
$$

The consumer surplus, CS, is the willingness to pay of cyclists to access [30]:

$$
C S=\int_{p_{0}{ }^{0}}^{p^{c}} x(\cdot) d C=\left[\frac{e^{\beta_{0}+\beta_{1} C}}{\beta_{1}}\right]_{C=C^{0}}^{C \rightarrow \infty}=-\frac{x}{\beta_{1}}
$$

In Equation (4), $C$ represents the travel cost, and $\beta_{1}$ is its coefficient. The relationship between the travel cost and the number of trips follows the demand rule, therefore $\beta_{1}$ is negative. The cyclists were asked the contingent behavior question: Under the scenario that trees on both sides of the bikeway were removed for $100 \mathrm{~m}$, how many times less would you ride bicycle here? Then, the effect of the damage can be estimated and compared to the consumer surplus indifferent trips.

\section{Results}

\subsection{Environmental Quality of the Bikeway}

The main socio-demographic characteristics of the respondents are listed in Appendix A Table A1. After the trees were destroyed, 50.5 percent the respondents would not ride bicycles on Dong-Feng bikeway. Principal component method and Varimax rotation procedure was used in exploratory factor analysis to extract the main components of the environmental quality of bikeways. Six items of the environmental quality on the questionnaire were dropped because their factor loading was small than 0.5 in the pre-test, including toilet number, toilet location, trash can number, trash can location, congestion, and local specialty products. As a result, five major components were extracted from 20 items, and the eigenvalues exceed 1 . The total variance was $72.91 \%$. The detail results of the factor analysis were revealed in Table 1.

\begin{tabular}{|c|c|c|c|c|c|}
\hline Items & $\begin{array}{l}\text { Lighting } \\
\text { Safety }\end{array}$ & Landscape & $\begin{array}{c}\text { Lane } \\
\text { Facility }\end{array}$ & Lane Design & $\begin{array}{c}\text { Lane } \\
\text { Dedicated }\end{array}$ \\
\hline Number of lights & 0.888 & & & & \\
\hline Brightness of lights & 0.867 & & & & \\
\hline Visibility of Signs at night & 0.831 & & & & \\
\hline Visibility of guard rails color at night & 0.777 & & & & \\
\hline Nighttime first-aid station & 0.750 & & & & \\
\hline Surrounding landscape & & 0.812 & & & \\
\hline Variety of surrounding views & & 0.730 & & & \\
\hline Tourist attractions nearby & & 0.705 & & & \\
\hline Shade along the bike path & & 0.605 & & & \\
\hline Signage (e.g., road signs, traffic signs ... etc.) & & & 0.785 & & \\
\hline Resting facilities (e.g., platforms, seats ... etc.) & & & 0.769 & & \\
\hline Guiding facilities (e.g., maps, leaflets ... etc.) & & & 0.746 & & \\
\hline Parking facilities & & & 0.632 & & \\
\hline Slopes of the bike path & & & & 0.856 & \\
\hline Width of the bike path & & & & 0.715 & \\
\hline Length of the bike path & & & & 0.677 & \\
\hline Condition of the pavement & & & & 0.534 & \\
\hline Road traffic control & & & & & 0.846 \\
\hline Guarantee of cyclists' road users rights. & & & & & 0.828 \\
\hline Security for the surrounding environment & & & & & 0.661 \\
\hline Eigenvalue & 8.832 & 2.184 & 1.375 & 1.162 & 1.029 \\
\hline Cumulative variation (\%) & 20.19 & 35.08 & 48.88 & 60.97 & 72.91 \\
\hline Cronbach's $\alpha$ & 0.93 & 0.82 & 0.86 & 0.80 & 0.87 \\
\hline
\end{tabular}

Table 1. Principal component analysis. 
The first component of environment quality was 'lighting safety', and the variance accounted for $20.19 \%$. The reliability is $93 \%$. The other four dimensions were 'landscape', 'facilities', 'lane design', and 'traffic control' factors; they accounted for $14.89 \%, 13.80 \%$, $12.09 \%$ and $11.94 \%$ of the total variance, respectively. Their coefficients reliabilities were $82 \%, 86 \%, 80 \%$ and $87 \%$, respectively. The five components of environmental quality were introduced into TCM model to estimate the effect of the environmental quality and the recreational benefit for cyclists.

\subsection{Travel Cost Model Estimates}

This study adopted TCM to estimate the recreational benefit of the cyclists who visited Dong-Feng Bikeway. The description of the variables and summary statistics are listed in Table 2. The dependent variable of model $\mathrm{A}$ is the number of trips cyclists took to Dong-Feng Bikeway in the past one year. For model B, the dependent variable is the intended trips cyclists would take to Dong-Feng Bikeway under the scenario that trees on both sides of the bikeway were removed for $100 \mathrm{~m}$. Factors EQF1 to EQF5 denote the factors of lighting safety, landscape, facilities, lane design, and traffic control, respectively.

Table 2. Description of the variables and summary statistics.

\begin{tabular}{|c|c|c|c|}
\hline Variable & Definition & Mean & SD \\
\hline TRIPS1 (Model A) & $\begin{array}{c}\text { The number of observed trips individuals took to Dong-Feng Bikeway during the past } \\
\text { one year. }\end{array}$ & 3.67 & 7.01 \\
\hline TRIPS2 (Model B) & $\begin{array}{l}\text { The intended trips individuals would take to Dong-Feng Bikeway under the scenario that } \\
\text { the soil conservation project got rid of the trees on both sides of the bikeway for } 100 \mathrm{~m} \text {. }\end{array}$ & 2.66 & 6.06 \\
\hline COST & $\begin{array}{c}\text { Travel costs to Dong-Feng Bikeway round trip, whicht is measured in New Taiwan } \\
\text { dollars (NT\$). }\end{array}$ & 814 & 774 \\
\hline SCOST & Travel costs of substitute site-Kenting National Park in Pingtung (NT\$). & 886 & 757 \\
\hline INCOME & The monthly income of the respondent (NT\$). & 38,900 & 20,705 \\
\hline EQF1 & $\begin{array}{l}\text { The factor score of 'Lighting safety'. } \\
\text { (Origin Likert scale) }\end{array}$ & $(3.37)$ & $(0.88)$ \\
\hline EQF2 & $\begin{array}{l}\text { The factor score of 'Landscape'. } \\
\text { (Origin Likert scale) }\end{array}$ & $(3.98)$ & $(0.86)$ \\
\hline EQF3 & $\begin{array}{l}\text { The factor score of 'Facilities'. } \\
\text { (Origin Likert scale) }\end{array}$ & $(3.86)$ & $(0.79)$ \\
\hline EQF4 & $\begin{array}{l}\text { The factor score of 'Lane design'. } \\
\text { (Origin Likert scale) }\end{array}$ & $(4.11)$ & $(0.83)$ \\
\hline EQF5 & $\begin{array}{l}\text { The factor score of 'Traffic control'. } \\
\text { (Origin Likert scale) }\end{array}$ & $(4.07)$ & $(0.89)$ \\
\hline $\mathrm{D}$ & $\begin{array}{l}\text { Dummy variable, } 1 \text {, if manytrees were planted to improve the landscape of Dong-Feng } \\
\text { bikeway, the respondents' intention to ride bike there would change; } 0 \text {, otherwise. }\end{array}$ & 0.51 & 0.50 \\
\hline
\end{tabular}

Note: The exchange rate of NT\$/US\$ = 30.925 in 2019.

The goodness-of-fit test of the Poisson models was examined by Chi-squared, which was estimated by likelihood ratio. The goodness-of-fit test revealed that the null hypothesis of estimation model was all independent variables coefficient being equal to zero, which was rejected at the 0.01 significance level. Based on demand rule, the signs of cost and substitute cost variables were negative for both models and differ from 0 significantly. The income variable was positive and significantly related to visiting frequencies of cyclists. Cyclists who had higher income and age were more lovely to ride to Dong-Feng Bikeway. The dummy variable $\mathrm{D}$ was also different from zero at $1 \%$ significantly, and that indicates cyclists' intention to ride on the bikeway if the landscape were improved. For the environment factors, in model A (before the trees of bikeway has destroyed), 'ighting safety' (EQF1), 'landscape' (EQF2), and 'lane design' (EQF4) were significantly related to cyclists' demand. In model B (destroyed trees on both sides of the bikeway), only 'lane design' (EQF4) was positively related to the demand. Lighting safety was negatively related to the demand, the Likert scale was the lowest in all factors (small than 3). The cyclists did not like to ride bicycle at night if there was not enough lighting facility and lane design 
were positively related to their demand. If lighting facility and landscape components were improved, the cyclists increased their intention to ride on the bikeway. The details are listed in Table 3.

Table 3. Estimation of travel cost model.

\begin{tabular}{|c|c|c|}
\hline Variable & Model A & Model B \\
\hline Constant & $\begin{array}{l}1.6279 \\
(4.546)\end{array}$ & $\begin{array}{l}1.1232 \\
(2.541)\end{array}$ \\
\hline COST & $\begin{array}{c}-0.0035^{* * *} \\
(-10.640)\end{array}$ & $\begin{array}{c}-0.0042^{* * *} \\
(-9.451)\end{array}$ \\
\hline SCOST & $\begin{array}{c}0.0034^{* * *} \\
(10.080)\end{array}$ & $\begin{array}{c}0.0041^{* * *} \\
(8.998)\end{array}$ \\
\hline INCOME & $\begin{array}{c}0.000006^{* * *} \\
(2.631)\end{array}$ & $\begin{array}{c}0.000006^{* *} \\
(2.145)\end{array}$ \\
\hline SAT & $\begin{array}{l}0.1158^{*} \\
(1.764)\end{array}$ & $\begin{array}{l}0.1143 \\
(1.399)\end{array}$ \\
\hline $\mathrm{D}$ & $\begin{array}{c}0.0604 \\
(34.839)^{* * * *}\end{array}$ & $\begin{array}{c}0.0691 \\
(35.623)^{* * *}\end{array}$ \\
\hline EQF1 & $\begin{array}{c}-0.0914^{* * *} \\
(3.886)\end{array}$ & $\begin{array}{c}-0.0307 \\
(1.069)\end{array}$ \\
\hline EQF2 & $\begin{array}{c}0.0598^{* *} \\
(2.371)\end{array}$ & $\begin{array}{l}0.0331 \\
(1.050)\end{array}$ \\
\hline EQF3 & $\begin{array}{l}0.0147 \\
(0.619)\end{array}$ & $\begin{array}{l}0.0181 \\
(0.623)\end{array}$ \\
\hline EQF4 & $\begin{array}{c}0.0510 * * \\
(1.992)\end{array}$ & $\begin{array}{l}0.0554 \text { * } \\
(1.720)\end{array}$ \\
\hline EQF5 & $\begin{array}{l}0.0347 \\
(1.413)\end{array}$ & $\begin{array}{l}0.0396 \\
(1.305)\end{array}$ \\
\hline Chi-squared & $1568^{* * *}$ & $1672 * * *$ \\
\hline
\end{tabular}

Note: ${ }^{* * *} p<0.01,{ }^{* *} p<0.05,{ }^{*} p<0.1$, and $\mathrm{t}$ values in parentheses.

\subsection{Estimating Recreational Benefits and Damage Effect}

The consumer surplus was calculated by Equation (4). The mean recreational benefit of a cyclist was NT\$750 for Model A and NT\$882 for Model B. A decrease was found for the damaged landscape; this was the damage cost for getting rid of the trees on both sides of the bikeway for the soil conservation project. The decrease amount of consumer surplus was NT\$132. Based on Taiwan Tourism Bureau's statistics in 2018, the number of tourists visiting the bikeway was 10 million, thus the total recreational benefits of cyclists decreased by NT\$1320 million. Yeh et al.'s (2019) research showed the effect of improving the environment of the bikeway before the trees were removed on both sides of Dong-Feng Bikeway [20]. Their research also revealed that the number of times cyclists riding on the bikeway would increase to 3.12 times under the contingent hypothetic scenario of landscape improvement. However, in this study it was found that after the landscape was destroyed, the number would be decreased to 1 time. The results indicated that landscape of bike paths was important to cyclists, and although the soil conservation project was taken to protect the environment, the project should take a step further to make sure that the landscape of the finished work could still appeal to the users of the bikeway.

\section{Discussion}

This study revealed that the deterioration of bikeway landscape decreased the recreational benefits for cyclists, which complements Yeh's et al. (2019) research and making this study a robust analysis [20]. The research of Yeh et al. (2019) revealed that improving environment quality of bikeway increased the intension of cyclists to the bikeway, which also increased the recreational benefits of cyclists who ride to bikeway [20]. The elasticity of improved quality in own-price, cross-price, and income become smaller than that for unchanged quality. The low elasticity of bikeway environment leads cyclists unchanged to ride on Dong-Feng Bikeway. This study found that after the landscape was destroyed, 
cyclists would like to decrease their intension for riding. The research of Han, Nelson, and Kim (2015) and Gangaas, Kaltenborn, and Andreassen (2015) exhibited that environmental value is strongly to determine the behavior of tourists $[49,50]$. The result is also in accord with the research of Kulczycki and Halpenny (2014) that rich amenities and landscape are crucial to cyclists [7], and reflects the research of Perić, Durkin, and Vitezić (2018) that natural environment is important to improve sport tourism experiences [19]. For these reasons, International Olympic Committee (IOC) is aware of the importance of environment and sustainable development, and makes environment the third component of Olympic movement [24]. The results of this study also support the concept of sport ecology that sport and environment is bidirectional and interacted for each other [51]. Future research should pay more attention to nature environment of sports activities that would lead a sustainable development in sport activities.

\section{Conclusions}

The main contribution of this study is the evaluation of the cyclists' intention behavior and the effect of damaged landscape based on the framework of TPB and TCM. The finding also demonstrates that the quality of the landscape is one very important factor to bike tourism. The theory of planned behavior has often been applied to social science research. The theoretical contribution is that combined TPB with contingent behavior concept, this study was able to predict the behavior of cyclists, to estimate the effect of damaged landscape as well as the recreational benefits for cyclists who visited to DongFeng Bikeway. The soil conservation project was implemented on Dong-Feng Bikeway to protect the environment; however, the finished work saw concrete grids replacing trees that provided shade to users of the bikeway, and concrete grids were definitely not the kind of landscape that cyclists went there for. Under the scenario of landscape damage, the number of trips went down by 1.01 times and the recreational benefit was reduced to NT $\$ 750$. Damaged landscape decreased cyclists' intention to ride bicycle there. In according to Taiwan Tourism Bureau's statistics, the total number of tourists visited Dong-Feng bikeway were $10,000,813$ in 2018 , and the number was decreased to 9,933,514 in 2019. The average recreational benefit for a cyclist is NT\$ 882, this means the cost of landscape damage is NT\$132. The result revealed that the quality of environment is important for cyclists, especially the landscape. Preserving the natural environment of cycle paths should go hand in hand with improving the landscape to encourage the use of cycle paths and to increase the benefits of their users. The study suggests that surely, to sustain bicycle tourism it is important to preserve the environment of bike paths, and there is no doubt that protecting the environment is among one of the most important issues in developing the sport. The natural environment quality is a crucial motivation for participants in sports. However, from the perspective of keeping the environment attractive to cyclists and preserving the environment should not be treated as separate issues. The development of bike tourism should pay attention to the policy of sport ecology that focus on the preservation of natural environment for sustainability.

Since the environmental effect and recreational benefits of cyclists cannot be estimated by market price, only the non-market goods method is suitable for the job. In this case, contingent behavior questions were added to TCM to measure both the landscape damage effect and the recreational benefits of cyclists simultaneously. However, the limitation of this study is that the study did not conduct a survey on non-visitors. Future research may follow the contingent behavior model (CBM) of Whitehead et al. (2000) combining current data and contingent behavior data to evaluate the effect of quality improvement or deterioration [38]. In addition, CBM can introduce non-visitors' samples to test potential structural change in the recreational demand of new participants offering more information to the research. 
Author Contributions: C.-C.Y. contributed the conceptualization summarization, investigation and supervision; C.J.-Y.L. writing-contributed origin idea, original draft preparation, review and editing; J.P.-H.H. investigation and data curation; C.-H.H. methodology, software, and formal analysis. All authors have read and agreed to the published version of the manuscript.

Funding: This research received no external funding.

Institutional Review Board Statement: Not applicable.

Informed Consent Statement: Not applicable.

Data Availability Statement: The data presented in this study are available on request from the corresponding author. The data are not publicly available due to privacy reasons.

Conflicts of Interest: The authors declare no conflict of interest.

\section{Appendix A}

Table A1. Socio-economic characteristics of respondents.

\begin{tabular}{|c|c|c|}
\hline Characteristics & Frequency & Percent (\%) \\
\hline \multicolumn{3}{|l|}{ Gender } \\
\hline Male & 140 & 36.6 \\
\hline Female & 242 & 63.4 \\
\hline \multicolumn{3}{|l|}{ Marital status } \\
\hline \multicolumn{3}{|l|}{ Married } \\
\hline Single & 245 & 64.1 \\
\hline Others & 109 & 28.5 \\
\hline Age & 28 & 7.4 \\
\hline $21 \sim 30$ & 81 & 21.2 \\
\hline $31 \sim 40$ & 95 & 24.9 \\
\hline $41 \sim 50$ & 123 & 32.2 \\
\hline $51 \sim 60$ & 68 & 17.8 \\
\hline Over 61 & 15 & 3.9 \\
\hline \multicolumn{3}{|l|}{ Education } \\
\hline Junior high school & 13 & 3.4 \\
\hline Senior high school & 70 & 18.3 \\
\hline Undergraduate & 242 & 63.4 \\
\hline Graduate school & 57 & 14.9 \\
\hline \multicolumn{3}{|l|}{ Monthly Income } \\
\hline Less than NT $\$ 20,000$ & 64 & 16.8 \\
\hline NT\$20,001 40,000 & 155 & 40.6 \\
\hline NT\$40,001 60,000 & 108 & 28.3 \\
\hline NT\$60,001 80,000 & 37 & 9.7 \\
\hline Over NT\$ 80,000 & 18 & 4.7 \\
\hline \multicolumn{3}{|c|}{$\begin{array}{c}\text { If the lighting facilities were improved, you would like to ride } \\
\text { here again }\end{array}$} \\
\hline Yes & 289 & 75.7 \\
\hline No & 93 & 24.3 \\
\hline \multicolumn{3}{|c|}{ After the trees destroyed, you would still like to ride here again } \\
\hline Yes & 189 & 49.5 \\
\hline No & 193 & 50.5 \\
\hline
\end{tabular}

\section{References}

1. Mullins, P.M. Living stories of the landscape: Perceptions of place through canoeing in Canada's north. Tour. Geogr. 2009, 11, 233-255. [CrossRef]

2. Maldonado-Hinarejos, R.; Sivakumar, A.; Polak, J.W. Exploring the role of individual attitudes and perceptions in predicting the demand for cycling: A hybrid choice modelling approach. Transportation 2014, 41, 1287-1304. [CrossRef]

3. MacIntosh, E.; Apostolis, N.; Walker, M. Environmental responsibility: Internal motives and customer expectations of a winter sport provider. J. Sport Tour. 2013, 18, 99-116. [CrossRef] 
4. Trendafilova, S.; Babiak, K.; Heinze, K. Corporate social responsibility and environmental sustainability: Why professional sport is greening the playing field. Sport Manage. Rev. 2013, 16, 298-313. [CrossRef]

5. Hodeck, A.; Hovemann, G. Motivation of active sport tourists in a German highland destination-a cross-seasonal comparison. J. Sport Tour. 2016, 30, 335-348. [CrossRef]

6. Relph, E. Responsive methods, geographical imagination and the study of landscapes. In Remaking Human Geography; Kobayashi, A., Mackenzie, A., Eds.; Unwin Hyman: Boston, MA, USA, 1989; pp. 149-163.

7. Kulczycki, C.; Halpenny, E.A. Sport cycling tourists' setting preferences, appraisals and attachments. J. Sport Tour. 2014, 19, 169-197. [CrossRef]

8. Lamont, M. Reinventing the wheel: A definitional discussion of bicycle tourism. J. Sport Tour. 2009, 14, 5-23. [CrossRef]

9. Ritchie, B.W.; Tkaczynski, A.; Faulks, P. Understanding the motivation and travel behavior of cycle tourists using involvement profiles. J. Travel Tour. Mark. 2010, 27, 409-425. [CrossRef]

10. LaChausse, R.G. Motives of competitive and non-competitive cyclists. J. Sport Behav. 2006, 29, 304-314.

11. Gat, I.; McWhirter, B.T. Personality characteristics of competitive and recreational cyclists. J. Sport Behav. 1998, 21, 408-420.

12. Williams, T. Sport, hegemony and subcultural reproduction: The process of accommodation in bicycle road racing. Int. Rev. Sociol. Sport 1989, 24, 315-333. [CrossRef]

13. Brown, T.D.; O'Connor, J.P.; Barkatsas, A. Instrumentation and motivations for organized cycling: The development of the cyclist motivation instrument (CMI). J. Sports Sci. Med. 2009, 8, 211-218. [PubMed]

14. O'Connor, J.P.; Brown, T.D. Riding with the sharks: Serious leisure cyclist's perceptions of sharing the road with motorists. J. Sci. Med. Sport 2010, 13, 53-58. [CrossRef] [PubMed]

15. Gibson, H.J.; Chang, S. Cycling in mid and later life: Involvement and benefits sought from a bicycle tour. J. Leis. Res. 2012, 44, 23-51. [CrossRef]

16. Perić, M.; Vitezić, V.; Mekinc, J. Conceptualizing innovative business models for sustainable sport tourism. Int. J. Sustain. Dev. Plan. 2016, 11, 469-482. [CrossRef]

17. Sener, I.N.; Eluru, N.; Bhat, C.R. An analysis of bicycle route choice preferences using a web-based survey to examine bicycle facilities. Transportation 2009, 36, 511-539. [CrossRef]

18. Stinson, M.A.; Bhat, C.R. Commuter bicyclist route choice: Analysis using a stated preference survey. Transport. Res. Rec. 2003, 1828, 107-115. [CrossRef]

19. Perić, M.; Durkin, J.; Vitezić, V. Active event sport tourism experience: The role of the natural environment, safety and security in event business models. Int. J. Sustain. Dev. Plan. 2018, 13, 758-772. [CrossRef]

20. Yeh, C.C.; Lin, C.Y.; Hsiao, P.H.; Huang, C.H. The Effect of Improving Cycleway Environment on the Recreational Benefits of Bicycle Tourism. Int. J. Environ. Res. Publ. Health 2019, 16, 3460. [CrossRef]

21. Spinney, J. A place of sense: A kinaesthetic ethnography of cyclists on Mont Ventoux. Environ. Plan. D 2006, $24,709-732$. [CrossRef]

22. Wicker, P.; Whitehead, J.C.; Mason, D.S.; Johnson, B.K. Public support for hosting the Olympic Summer Games in Germany: The CVM approach. Urban Stud. 2017, 54, 3597-3614. [CrossRef]

23. Cantelon, H.; Letters, M. The making of the IOC environmental policy as the third dimension of the Olympic Movement. Int. Rev. Sociol. Sport 2000, 35, 294-308. [CrossRef]

24. Beyer, S. The green Olympic movement: Beijing 2008. Chin. J. Int. Law 2006, 5, 423-440.

25. Westerbeek, H.M.; Turner, P.; Ingerson, L. Key success factors in bidding for hallmark sporting events. Int. Mark. Rev. 2002, 19, 303-322. [CrossRef]

26. Hightower, R.; Brady, M.K.; Baker, T.L. Investigating the role of the physical environment in the hedonic service consumption: An exploratory study of sporting events. J. Bus. Res. 2002, 55, 697-707. [CrossRef]

27. Mihali ${ }^{`} \mathrm{c}, \mathrm{T}$. Environmental management of a tourist destination- A factor of tourism competitiveness. Tour. Manage. 2000, 21, 65-78. [CrossRef]

28. Bull, C.J. Racing cyclists as sports tourists: The experiences and behaviours of a case study group of cyclists in East Kent, England. J. Sport. Tour. 2006, 11, 259-274. [CrossRef]

29. Ma, L.; Dill, J.; Mohr, C. The objective versus the perceived environment: What matters for bicycling? Transportation 2014, 41, 1135-1152. [CrossRef]

30. Huang, C.H. Estimating the environmental effects and recreational benefits of cultivated flower land for environmental quality improvement in Taiwan. Agric. Econ. 2017, 48, 29-39. [CrossRef]

31. Downward, P.; Lumsdon, L. The development of recreational cycle routes: An evaluation of user needs. Manag. Leis. 2001, 6, 50-60.

32. Chen, C.; Chen, P. Estimating recreational cyclists' preferences for bicycle routes-Evidence from Taiwan. Transp. Policy 2013, 26, 23-30. [CrossRef]

33. Lamont, M.; Buultjens, J. Putting the brakes on: Impediments to the development of independent cycle tourism in Australia. Curr. Issues Tour. 2011, 14, 57-78. [CrossRef]

34. Burk, D. Infrastructure, social practice, and environmentalism: The case of bicycle-commuting. Soc. Force 2017, 95, 1209-1236. [CrossRef] 
35. Cunningham, G.B.; Kwon, H. The theory of planned behaviour and Intentions to Attend a Sport Event. Sport Manage. Rev. 2003, 6, 127-145. [CrossRef]

36. Ajzen, I. The theory of planned behavior. Organ. Behav. Hum. Decis. Process. 1991, 50, 179-211. [CrossRef]

37. Hagger, M.S.; Chatzisarantis, N.; Biddle, S.J.H. The influence of self-efficacy and past behavior on the physical activity intentions of young people. J. Sports Sci. 2001, 19,711-725. [CrossRef]

38. Jeon, H.; Herriges, J.A. Combining revealed preference data with stated preference data: A Latent class approach. Environ. Resour. Econ. 2017, 68, 1053-1086. [CrossRef]

39. Whitehead, J.C.; Haab, T.C.; Huang, J.C. Measuring recreation benefits of quality improvements with revealed and stated behavior data. Resour. Energy Econ. 2000, 22, 339-354. [CrossRef]

40. Parasuraman, A.; Grewal, D. The impact of technology on the quality-value-loyalty chain: A research agenda. J. Acad. Mark. Sci. 2000, 28, 168-170. [CrossRef]

41. Whitehead, J.C.; Wicker, P. Estimating willingness to pay for a cycling event using a willingness to travel approach. Tour. Manage. 2018, 65, 160-169. [CrossRef]

42. Carson, R.T.; Flores, E.N.; Martin, M.K.; Wright, L.J. Contingent valuation and revealed preference methodologies: Comparing the estimates for qusi-public goods. Land Econ. 1996, 72, 80-89. [CrossRef]

43. Common, M.; Bull, T.; Stoeckl, N. The travel cost method: An empirical investigation of Randall's Difficulty. Aust. J. Agri. Resour. Econ. 1999, 43, 457-477. [CrossRef]

44. Bockstael, N.E.; Strand, I.E.; Hanemann, W.M. Time and the recreational demand model. Am. J. Agric. Econ. 1987, 69, 293-302. [CrossRef]

45. McConnell, K.E.; Strand, I. Measuring the cost of time in recreational demand analysis: An application to sport fishing. Am. J. Agric. Econ. 1981, 63, 153-156. [CrossRef]

46. Rosenthal, D.H. The necessity for substitute prices in recreation demand analysis. Am. J. Agric. Econ. 1987, 69, 828-837. [CrossRef]

47. Shaw, D. On-site samples' regression: Problem of non-negative integers, truncation and endogenous stratification. J. Econom. 1988, 37, 211-223. [CrossRef]

48. Chakraborty, K.; Keith, J.E. Estimating the recreation demand and economic value of mountain biking in Moab, Utah: An application of count data models. J. Environ. Plan. Manag. 2000, 43, 461-469. [CrossRef]

49. Han, J.H.; Nelson, C.M.; Kim, C. Proenvironmental behavior in sport event tourism: Roles of event attendees and destinations. Tour. Geogr. 2015, 17, 719-737. [CrossRef]

50. Gangaas, K.E.; Kaltenborn, B.P.; Andreassen, H.P. Environmental attitudes associated with large-scale cultural differences, not local environmental conflicts. Environ. Conser. 2015, 42, 41-50. [CrossRef]

51. McCullough, B.P.; Orr, M.; Kellison, T. Sport ecology: Conceptualizing an emerging subdiscipline within sport management. J. Sport Manag. 2020, 34, 509-520. [CrossRef] 